\title{
ANALISIS KONSUMSI DAN BIAYA BAHAN BAKAR PADA MESIN PARUT KELAPA BERBAHAN BAKAR GAS
}

\author{
Achmad Rijanto \\ Teknik Mesin, Fakultas Teknik, Universitas Islam Majapahit, e-mail: rijanto1970@gmail.com

\section{Imaduddin Bahtiar Efendi} \\ Teknik Industri, Fakultas Teknik Universitas Islam Majapahit, e-mail: imaduddinbe@gmail.com
}

\begin{abstract}
Abstrak
Kenaikan harga bahan bakar minyak (BBM) dan listrik menyebabkan biaya operasional produksi dengan menggunakan mesin parut kelapa ini menjadi semakin besar pula. Hal ini menjadi masalah bagi industri yang mengolah hasil pertanian yang menggunakan mesin ini. Oleh karena itu perlu dicari upaya untuk menekan biaya operasional produksi melalui pengurangan biaya penggunaan bahan bakarnya. Upaya tersebut adalah dengan cara menggunakan bahan bakar yang lebih murah dari penggunaan BBM.Upaya yang dilakukan adalah penerapan konversi BBM ke BBG untuk mesin parut kelapa. Oleh karea itu perlu dilakukan penelitian untuk menganalisis konsumsi dan biaya BBG. Tujuan dari penelitian ini adalah untuk menganalisis banyaknya bahan bakar yang digunakan dan biaya bahan bakar pada mesin parut kelapa dengan menggunakan bahan bakar gas (BBG). Bahan bakar yang digunakan, bahan bakar Liquified Petroleum Gas (LPG) $3 \mathrm{~kg}$. Metode yang digunakan dalam penelitian ini adalah metode eksperimental. Dari hasil penelitian, diperoleh bahwa besarnya konsumsi bahan bakar gas LPG pada putaran mesin $1.900 \mathrm{rpm}$ sebesar $0,136 \mathrm{~kg} / \mathrm{jam}-0,152 \mathrm{~kg} / \mathrm{jam}$, sedangkan biaya bahan bakar gas LPG yang digunakan sebesar Rp 816,-/jam - Rp 912,-/jam.

Kata kunci: konsumsi, biaya, bahan bakar gas, mesin parut kelapa
\end{abstract}

\section{Abstract}

The increase in the price of fuel oil (BBM) and electricity costs caused the operational costs of production using this coconut grated machine to become even greater. This is a problem for industries that process agricultural products using this machine. Therefore, it is necessary to make efforts to reduce operating costs for the cost of using fuel. These efforts are by using fuel that is cheaper than the use of BBM. Efforts are being made to implement conversion of BBM to BBG for coconut grated machines. Therefore, it is necessary to conduct research to analyze the consumption and costs of BBG. The purpose of this research is to analyze the amount of fuel used and the cost of fuel in the machine grated coconut using gas fuel $(B B G)$. The fuel used is $3 \mathrm{~kg}$ Liquified Petroleum Gas (LPG) fuel. The method used in this study is an experimental method. From the results of the study, it was found that the price of LPG gas fuel at 1,900 rpm engine speed was 0,136 kg/ hour - 0,152 kg / hour, while the cost of LPG gas fuel which was Rp. 816, - / hour - Rp. 912, - / hour.

Keywords: consumption, cost, gas fuel, coconut grated machine

\section{PENDAHULUAN}

Cadangan bahan bakar minyak (BBM) dan mengalami penurunan, sedangkan produksi gas bumi mengalami peningkatan. Kondisi ini dapat dilihat pada produksinya kian hari semakin menurun, sehingga berdampak pada semakin mahalnya harga BBM tersebut. Oleh karena itu perlu adanya inovasi baru terhadap teknologi penggunaan bakar bakar alternatif sebagai konversi dari penggunaan BBM.

Teknologi konversi bahan bakar beraneka ragam, salah satunya teknologi konversi penggunaan BBM ke bahan bakar gas (BBG). Pemilihan gas alam sebagai pengkonversi BBM, dikarenakan gas alam di Indonesia mempunyai jumlah produksi yang semakin meningkat, pengadaan kelengkapan infrasruktur, harganya lebih murah dari BBM, dan ramah lingkungan. Berdasarkan renstra Kementrian Energi dan Sumber Daya Mineral (ESDM), Direktorat Jendral Minyak dan Gas Bumi, tahun 2015-2019, kondisi produksi minyak bumi gambar 1.

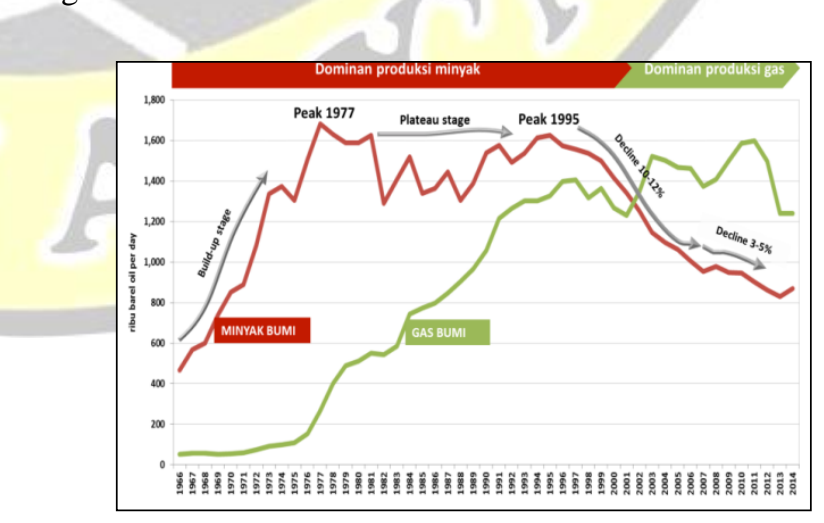

Gambar 1. Grafik Perkembangan produksi minyak bumi dan gas bumi 
Potensi minyak dan gas bumi di Indonesia memiliki potensi hidrokarbon di 60 cekungan sedimen. Bahkan hasil penelitian Badan Geologi terakhir diidentifikasi cekungan migas sebanyak 128 cekungan. Cadangan terbukti minyak bumi tahun 2014 sebesar 3,6 miliar barel dan dengan tingkat produksi saat ini maka usianya sekitar 13 tahun. Sedangkan cadangan gas bumi tahun 2014 sebesar 100,3 TCF dan akan bertahan selama 34 tahun. Usia cadangan migas, diasumsikan apabila tidak ada penemuan cadangan migas baru. Dalam 5 tahun terakhir, cadangan migas mengalami penurunan sebagaimana tabel di bawah ini. Perkembangan cadangan minyak dan gas bumi dapat dilihat pada gambar 2 .

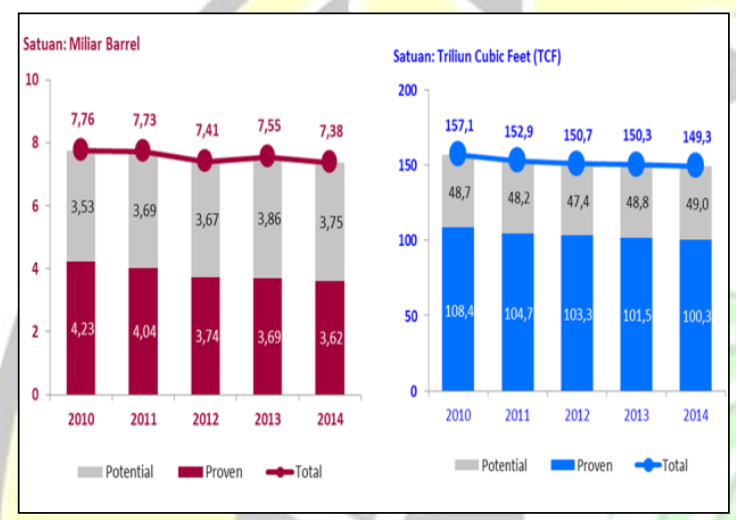

Gambar 2. Grafik cadangan minyak dan gas bumi Indonesia

Dari sumber resmi website Kementrian Energi dan Sumber Daya Mineral juga dapat ditampilkan pula pemenuhan infrastruktur konversi BBM ke BBG, pada gambar 3.

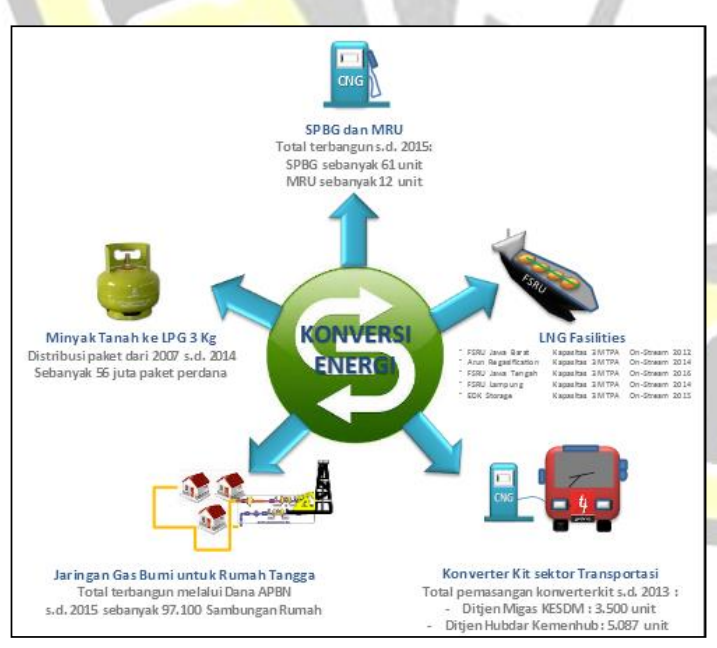

Gambar 3. Infrastruktur konversi BBM ke BBG

Dilihat dari komposisi emisi gas buang yang dihasilkan BBG (LPG) lebih ramah lingkungan dibandingkan dengan BBM (bensin). Menurut Singh dkk
(2015), perbandingan emisi gas buang bensin dan LPG, dapat dilihat pada tabel 1 .

Tabel 1. Tabel emisi gas buang bensin dan LPG

\begin{tabular}{cccc}
\hline No & Emisi & Bensin & LPG \\
\hline 1 & $\mathrm{CO}(\mathrm{gm} / \mathrm{Km})$ & 0,87 & 0,72 \\
\hline 2 & $\mathrm{HC}(\mathrm{gm} / \mathrm{Km})$ & 0,14 & 0,12 \\
\hline 3 & Nox $(\mathrm{gm} / \mathrm{Km})$ & 0,16 & 0,13 \\
\hline
\end{tabular}

Di bidang permesinan proses produksi banyak mesin yang masih menggunakan BBM sebagai sumber energinya, salah satunya adalah mesin parut kelapa. Mesin parut kelapa dipasaran masih menggunakan BBM (bensin atau solar) dan listrik sebagai sumber energinya. Mesin parut kelapa ini digunakan oleh industri yang mengolah hasil pertanian seperti kelapa, singkong, jagung dan lain-lain. Mesin parut kelapa yang digunakan di industri kecil masih banyak menggunakan bahan bakar minyak (BBM).

\section{Tabel 2. Harga BBM tahun 2017}

\begin{tabular}{|l|l|}
\hline Nama & Harga \\
\hline Premium (Jamali) & Rp. 6.550 per liter \\
\hline Pertalite & Rp. 7.400 per liter \\
\hline Pertamax & Rp. 8.250 per liter \\
\hline Pertamax Turbo & Rp. 9.250 per liter \\
\hline Dexlite & Rp. 7.300 per liter \\
\hline Pertamina Dex & Rp. 8.500 per liter \\
\hline Solar & Rp. 5.150 per liter \\
\hline
\end{tabular}

Tabel 3. Harga BBG LPG tahun 2017

\begin{tabular}{|l|l|}
\hline HARGA LPG 3 KG MELON & Rp. 140.000 \\
\hline HARGA LPG 3 KG MELON (Isi Ulang) & Rp. 15.400 \\
\hline HARGA LPG BRIGHT GAS5.5 KG & Rp. 265.000 \\
\hline HARGA LPG BRIGHT GAS 5.5 KG (Isi Ulang) & Rp. 60.990 \\
\hline HARGA LPG 12 KG & Rp. 345.000 \\
\hline HARGA LPG 12 KG (Isi Ulang) & Rp. 127.400 \\
\hline
\end{tabular}

Kenaikan harga BBM dan listrik menyebabkan biaya operasional produksi dengan menggunakan mesin parut kelapa ini menjadi semakin besar pula. Hal ini menjadi masalah bagi industri yang mengolah hasil pertanian yang menggunakan mesin ini. Oleh karena itu perlu dicari upaya untuk menekan biaya operasional produksi melalui pengurangan biaya penggunaan bahan bakarnya. Upaya tersebut adalah dengan cara menggunakan bahan bakar yang lebih murah dari penggunaan BBM. Dari sumber website resmi bph migas 
harga BBM tahun 2017 untuk wilayah Jakarta, dapat dilihat pada tabel 2., dan harga LPG tahun 2017 (listharga.com) pada tabel 3. Berdasarkan perbandingan harga di atas, sebagai alternatif pilihan bahan bakar yang digunakan untuk sumber energi mesin parut kelapa yaitu bahan bahan gas (BBG).

Dengan adanya mesin parut kelapa dengan menggunakan bahan bakar gas, maka perlu diteliti konsumsi dan biaya bahan bakar yang digunakannya. Konsumsi bahan bakar diartikan sebagai ukuran bahan bakar yang dikonsumsi mesin untuk menghasilkan tenaga mekanis, dan biaya bahan bakar adalah banyaknya biaya yang dikeluarkan selama mesin bekerja.

Buah kelapa merupakan salah satu buah-buahan yang tumbuh subur di Indonesia. Buah kelapa banyak diambil manfaatnya, mulai dari pohon, kulit, tempurung dan daging buah kelapa. Menurut Subagio (2011), Buah kelapa yang sudah tua mengandung kalori yang tinggi, sebesar 354 kal per 100 gram, yang berasal dari minyak kurang lebih 33 persen, karbohidrat 15 persen dan protein 3 persen. Kualitas protein daging buah kelapa sangat baik, karena mempunyai asam amino yang tinggi, dan tidak mengandung senyawa anti nutrisi. Dan dengan asam lemak rantai medium (MCFA) yang tinggi, minyak kelapa sangat sehat. Selanjutnya, kandungan galaktomannan dan fosfolipid yang tinggi menjadikan daging buah kelapa mempunyai kemampuan untuk memperbaiki karakter bahan pangan.

Hardono (2017), mesin parut kelapa adalah suatu alat yang digunakan untuk membantu atau mempermudah pekerjaan manusia dalam hal pemarutan kelapa. Sumber tenaga utama mesin parut adalah tenaga motor, dimana tenaga motor digunakan untuk menggerakkan atau memutar mata parut melalui perantara sabuk (V-belt). Mesin parut kelapa ini mempunyai sistem transmisi berupa puli. Gerak putar dari motor listrik ditransmisikan ke puli 1, kemudian dari puli 1 ditransmisikan ke puli 2 dengan menggunakan sabuk. Ketika motor dihidupkan, maka motor akan berputar, kemudian putaran ditransmisikan oleh sabuk untuk menggerakan poros mata parut. Dalam kehidupan sehari-hari kita sering menjumpai mesin pemarut kelapa, biasanya sering kita lihat di pasar-pasar. Mesin parut kelapa yang sudah ada antara lain:

1. mesin parut dengan menggunakan motor bensin berkapasitas 2 PK. Mesin ini menggunakan sumber energi Bahan Bakar Minyak (BBM) jenis bensin. Mesin ini banyak digunakan di industri kecil dan di pasar-pasar.

2. mesin parut dengan menggunakan motor listrik 0,5 HP. Mesin ini menggunakan sumber energi listrik sebagai penggerak motor. Daya listrik yang digunakan sebesar 125 watt. Mesin ini banyak digunakan di industri kecil atau di rumah tangga.

Motor bakar digunakan sebagai motor penggerak. Ramelan (2015), motor bakar atau lebih dikenal dengan nama mesin pembakaran dalam (internal combustion engine) adalah suatu jenis pesawat yang prinsip kerjanya mengubah energi kimia bahan bakar menjadi energi kalor, kemudian diubah lagi menjadi energi mekanik atau gerak. Proses pembakaran berlangsung di dalam motor bakar itu sendiri, sehingga gas pembakaran yang terjadi sekaligus berfungsi sebagai fluida kerja. Motor bakar ditinjau dari prinsip kerjanya dibagi menjadi dua macam, yaitu :

1. Motor 2 Langkah: Pada prinsipnya cara kerja motor bakar dua langkah sama dengan cara kerja motor bakar empat langkah. Pada motor bakar dua langkah proses kerjanya terjadi diatas piston dan dibawah piston yaitu langkah kompresi, langkah usaha dan pembilasan, dalam dua kali langkah piston dan satu kali putaran poros engkol.

2. Motor 4 langkah: Prinsip kerja motor bakar empat langkah adalah menyelesaikan satu siklus, yaitu : pengisian, kompresi, penyalaan, kerja dan pembuangan dalam empat kali langkah piston dan dua kali putaran poros engkol.

Salah satu bahan bakar minyak (BBM) yang sering digunakan adalah bensin. Ramelan (2015), bensin adalah zat cair yang diperoleh dari hasil pemurnian minyak bumi yang dapat digunakan sebagai bahan bakar motor bensin. Sebagai bahan bakar, bensin mempunyai komposisi elemen-elemen Carbon, Hidrogen, Nitrogen, Sulphur, Oksigen dan elemen lain seperti abu (ash), dan air (moisture). Bahan tembahan bensin yang utama adalah suatu bahan anti knock (detonasi) atau suara menggelitik pada mesin yang sering disebut Timah Tetra Ethyl (C2H5)4 $\mathrm{Pb}$ atau Tetra ethyl Lead. Selain itu ada suatu tambahan pada bensin yaitu:

a. Oxidation inhibitor yaitu untuk membantu mencegah terbentuknya karat sementara bensin disimpan.

b. Metal deactivators yaitu untuk melindungi bensin dari efek yang merugikan terhadap metal tertentu selama proses penyulingan atau didalam sistem bahan bakar kendaraan.

c. Bahan anti karat (anti rust agent) yaitu untuk melindungi sistem bahan bakar kendaraan dari kemungkinan berkarat.

d. Anti acers yaitu untuk menghilangkan pembekuan didalam karburator dan pipa bahan bakar.

e. Ditergent yaitu untuk mempertahankan kebersihan karburator.

Bahan Bakar Gas (BBG) salah satunya adalah LPG. LPG sudah dikemas dalam tabung. Ada yang berukuran 
$12 \mathrm{~kg}$ dan ada yang yang berukuran tabung $3 \mathrm{~kg}$, dapat dilihat pada gambar 4 .

ELPIJI $12 \mathrm{Kg}$
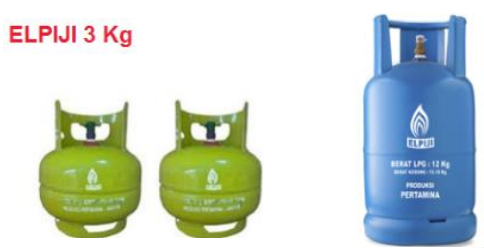

Gambar 4. LPG $3 \mathrm{~kg}$ dan $12 \mathrm{~kg}$

Menurut Bambang dan Kusuma (2015), LPG (liquified petroleum gas) adalah campuran dari berbagai unsur hidrokarbon yang berasal dari gas alam. Dengan menambah tekanan dan menurunkan suhunya, gas berubah menjadi cair. Komponennya didominasi propana (C3H8) dan butana (C4H10).

Pada awalnya, gas LPG tidak berbau, tapi bila demikian akan sulit dideteksi apabila terjadi kebocoran pada tabung gas. Menyadari itu Pertamina menambahkan gas mercaptan, yang baunya khas dan menusuk hidung. Langkah itu sangat berguna untuk mendeteksi bila terjadi kebocoran tabung gas. Dari website autogasindo perbandingan sifat atau karakterik bahan bakar LPG dengan bahan bakar premium dapat dilihat pada tabel 4 .

Tabel 4. Perbandingan karakteristik premium dengan LPG

\begin{tabular}{|c|l|c|c|}
\hline$N_{0}$ & \multicolumn{1}{|c|}{ Karekteristik } & Premium & LPG \\
\hline 1 & Komposisi & $\mathrm{C}_{8} \mathrm{H}_{18}$ & $\mathrm{C}_{3} \mathrm{H}_{8}$ \\
\hline 2 & Densitas & $752 \mathrm{~kg} / \mathrm{m}^{3}$ & $1,5 \mathrm{~kg} / \mathrm{m}^{3}$ \\
\hline 3 & Berat molekul & $114,8 \mathrm{~kg} / \mathrm{kmol}$ & $44,09 \mathrm{~kg} / \mathrm{kmol}$ \\
\hline 4 & Nilai kalori & $45950 \mathrm{kj} / \mathrm{kmol}$ & $46360 \mathrm{kj} / \mathrm{kmol}$ \\
\hline 5 & AFR stoikiometr & 14,57 & 15,6 \\
\hline 6 & Temperatur penyalaan min. & $360^{\circ} \mathrm{C}$ & $460^{\circ} \mathrm{C}$ \\
\hline 7 & Kecepatan nyala & $20-40 \mathrm{~m} / \mathrm{s}$ & $0,82 \mathrm{~m} / \mathrm{s}$ \\
\hline 8 & Angka oktan & 88 & 110 \\
\hline
\end{tabular}

Putaran mesin mempunyai pengaruh terhadap konsumsi bahan bakar. Menurut Alfatani (2015) semakin besar putaran mesin semakin besar pula konsumsi bahan bakar. Jadi untuk memperoleh konsumsi bahan bakar yang rendah, maka diperlukan putaran mesinyang terendah.

Konsumsi bahan bakar merupakan ukuran bahan bakar yang dikonsumsi motor untuk menghasilkan tenaga mekanis, laju pemakaian bahan bakar tiap detiknya (Ariawan dan Adnyana, 2016), dapat ditentukan dengan persamaan:

$$
\dot{M}_{f}=\frac{\dot{M}_{b}}{\Delta t}
$$

$\dot{M}_{f} \quad$ = konsumsi bahan bakar (gr/ det) atau (kg/ jam)

$\dot{M}_{b} \quad=$ massa bahan bakar (gr) atau $(\mathrm{kg})$

$\Delta t \quad=$ waktu yang diperlukan (det) atau (jam)

Biaya bahan bakar gas merupakan banyaknya biaya yang dikeluarkan selama motor bekerja atau hasil kali dari konsumsi bahan bakar dengan harga bahan bakar persatuan massa bahan bakar (Yohana dan Askhabulyamin, 2012), dapat ditentukan dengan persamaan 2:

$$
B_{b b g}=\dot{M}_{f} \times H_{b b g}
$$

$B_{b b g} \quad=$ biaya bahan bakar gas $(\mathrm{Rp} / \mathrm{jam})$

$\dot{M}_{f} \quad=$ konsumsi bahan bakar $(\mathrm{kg} / \mathrm{jam})$

$H_{b b g} \quad=$ harga bahan bakar gas $(\mathrm{Rp} / \mathrm{kg})$

\section{METODE}

Metode penelitian yang digunakan dalam penelitian ini adalah metode eksperimen. Diagram alur penelitian dapat dilihat pada gambar 5 .
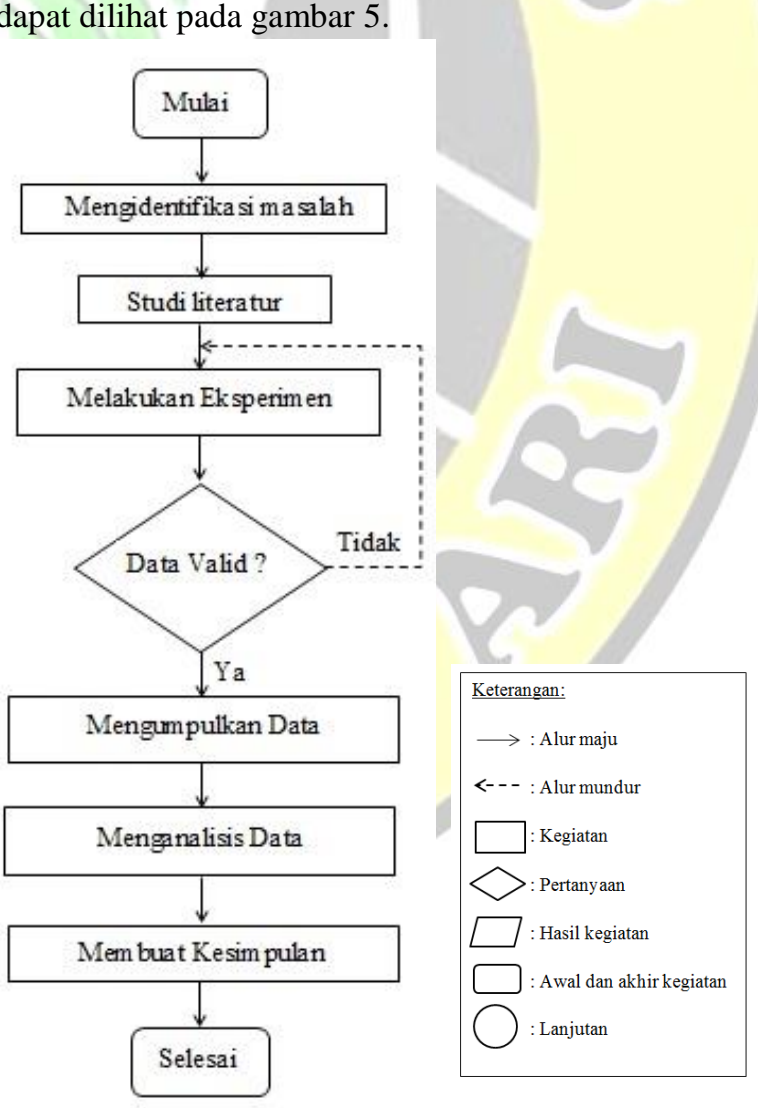

Gambar 5. Diagram alur penelitian

Langkah-langkah penelitian dari gambar 5 . dijelaskan sebagai berikut: 
1. mengidentifikasi masalah, menentukan rumusan masalah yang akan diteliti, yaitu meneliti konsumsi dan biaya bahan bakar gas LPG pada mesin parut kelapa berbahan bakar gas.

2. melakukan studi literatur atau kajian pustaka terhadap masalah yang diteliti.

3. melakukan eksperimen atau percobaan untuk memperoleh data.

4. mengumpulkan data penelitian yang valid.

5. menganalisis data hasil penelitian dan sekaligus membahas hasil penelitian.

6. mengambil kesimpulan dari hasil analisis dan pembahasan serta memberikan saran untuk melakukan penelitian lebih lanjut.

Penelitian dilakukan selama dua bulan. Lokasi penelitian dilaksanakan di Universitas Islam Majapahit Mojokerto, Fakultas Teknik, Program Sudi Teknik Mesin.

Alat dan bahan yang dibutuhkan pada penelitian ini meliputi:

1. mesin parut kelapa berbahan bakar gas (LPG) $3 \mathrm{~kg}$. Mesin ini digunakan sebagai obyek penelitian. Mesin parut kelapa berbahan bakar gas dapat dilihat pada gambar 6. Mesin yang digunakan mempunyai spesifikasi daya $5,5 \mathrm{hp}$, tipe mesin air cooled 4 tak, volume silinder $163 \mathrm{cc}$, bore $x$ stroke 68 x $45 \mathrm{~mm}$, kecepatan tanpa beban $3600 \mathrm{rpm}$, starter recoil, kapasitas oli 0,6 liter, diameter shaft $20 \mathrm{~mm}$ (operation manual book).

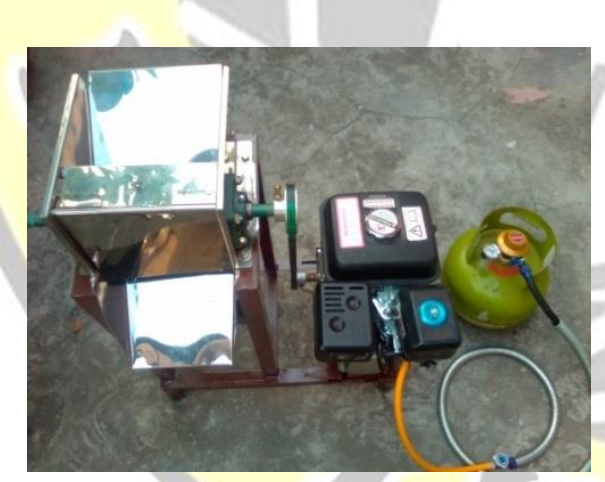

Gambar 6 . Mesin parut kelapa menggunakan bahan bakar LPG $3 \mathrm{~kg}$

2. tachometer digital non kontak (digital photo tachometer). Alat ini digunakan untuk mengukur putaran mesin. Alat ini dapat mengkur putaran mesin dari 2,5 rpm sampai $99.999 \mathrm{rpm}$. Spesifikasi yang lain; layar 5 digits, $18 \mathrm{~mm}$, tingkat akurasi $\pm 0,05 \%+$ 1 digit, resolution 0,1 rpm (2,5-999,9), $1 \mathrm{rpm}$ (diatas $1000 \mathrm{rpm}$ ), sampling time 0,8 detik di atas $60 \mathrm{rpm}$, test range select automatic dan cicuit exclusif one- chip of microcomputer LSI circuit, (operation manual book). Alat ini dapat dilihat pada gambar 7 .

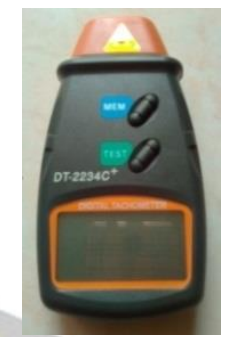

Gambar 7. Tachometer digital

3. timbangan digital. Alat ini digunakan untuk mengukur massa tabung gas beserta isinya. Ukuran maksimal sampai $40 \mathrm{~kg}$. Alat ini dilengkapi high precision strain gauge sensor, division 0,1-1 g, layar 0,6 ", aotomatic zero resetting, low power indicator, tare, two model unit (operation manual sheet).Dengan tingkat ketelitian 1 gram. Alat ini dapat dilihat pada gambar 8 .
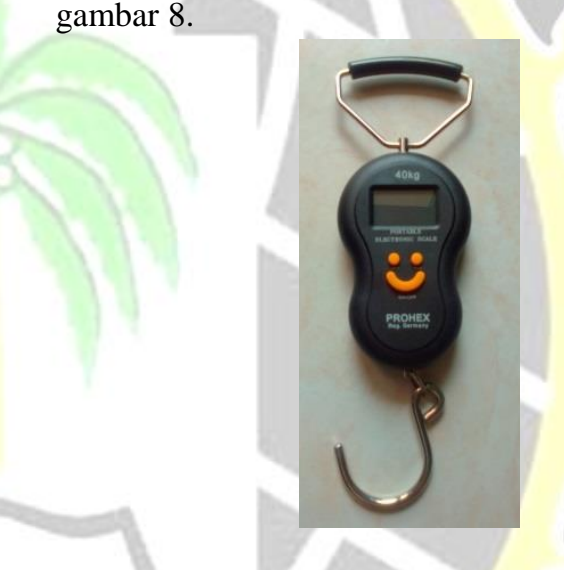

Gambar 8. Timbangan digital

\section{HASIL DAN PEMBAHASAN}

Berdasarkan hasil eksperimen yang telah dilakukan diperoleh data hasil penelitian sebagai berikut. Data dapat dilihat pada tabel 5 .

Tabel 5. Data hasil penelitian

\begin{tabular}{cccccc}
\hline $\begin{array}{c}\text { Percb } \\
. \mathrm{ke}\end{array}$ & $\begin{array}{c}n \\
(\mathrm{rpm})\end{array}$ & $\begin{array}{c}\Delta t \\
(\mathrm{mnt})\end{array}$ & $\begin{array}{c}M_{0} \\
(\mathrm{gr})\end{array}$ & $\begin{array}{c}M_{1} \\
(\mathrm{gr})\end{array}$ & $\begin{array}{c}\dot{M}_{b} \\
(\mathrm{gr})\end{array}$ \\
\hline 1 & 1.900 & 15 & 7.973 & 7.937 & 36 \\
\hline 2 & 1.900 & 15 & 7.937 & 7.900 & 37 \\
\hline 3 & 1.900 & 15 & 7.900 & 7.862 & 38 \\
\hline 4 & 1.900 & 15 & 7.862 & 7.828 & 34 \\
\hline 5 & 1.900 & 15 & 7.828 & 7.793 & 35 \\
\hline
\end{tabular}

$n=$ putaran mesin (rpm)

$M_{0}=$ massa awal tabung gas LPG beserta Isi (gr atau kg) 
$M_{l}=$ massa awal tabung gas LPG beserta Isi (gr atau kg)

$\Delta t=$ waktu pemakaian LPG (menit atau jam)

$\dot{M}_{b}=M_{0}-M_{l}=$ massa LPG yang dipakai (gr atau $\mathrm{kg}$ )

Untuk memperoleh data penelitian di atas dilakukan langkah-langkah eksperimen sebagai berikut:

1. menyiapkan bahan dan alat eksperimen.

2. mengukur massa awal tabung gas LPG $\left(M_{0}\right)$ yang sudah terisi gas LPG, dengan menggunaan timbangan digital.

3. menghubungkan tabung LPG dengan selang bahan bakar gas.

4. menghidupkan mesin (on) selama 15 menit.

5. mengukur putaran mesin $(n)$ dengan menggunakan tachometer digital ditentukan pada putaran terendah sebesar $1.900 \mathrm{rpm}$.

6. mesin memutar beban yang sama, yaitu berupa mata parut kelapa.

7. mesin menyala selama 15 menit $(\Delta t)$, seteah itu mesin dimatikan.

8. melepas tabung LPG dari selang dan mengukur massa akhir tabung LPG $\left(M_{l}\right)$.

9. eksperimen dilakukan berulang-ulang sampai memperoleh data hasil penelitian yang valid.

Dari data hasil penelitian dapat dianalisis bahwa pada kondisi putaran mesin (n) $1.900 \mathrm{rpm}$, waktu pemakaian LPG $(\Delta t) 15$ menit $(0,25$ jam) dan beban mata parut kelapa yang sama diperoleh:

1. masssa LPG yang digunakan $\left(\dot{M}_{b}\right)$ sebesar 36 gr pada percobaan pertama. Hal ini diperoleh dari selisih massa awal tabung gas dan isi $\left(M_{0}\right)$ sebesar $7.973 \mathrm{gr}$ terhadap massa akhir tabung gas dan isi $\left(M_{l}\right)$ sebesar $7.937 \mathrm{gr}$.

2. masssa LPG yang digunakan $\left(\dot{M}_{b}\right)$ sebesar 37 gr pada percobaan kedua. Hal ini diperoleh dari selisih massa awal tabung gas dan isi $\left(M_{0}\right)$ sebesar 7.937 gr terhadap massa akhir tabung gas dan isi $\left(M_{l}\right)$ sebesar 7.900gr.

3. masssa LPG yang digunakan $\left(\dot{M}_{b}\right)$ sebesar 38 gr pada percobaan ketiga. Hal ini diperoleh dari selisih massa awal tabung gas dan isi $\left(M_{0}\right)$ sebesar 7.900 gr terhadap massa akhir tabung gas dan isi $\left(M_{l}\right)$ sebesar 7.862 gr.

4. masssa LPG yang digunakan $\left(\dot{M}_{b}\right)$ sebesar 34 gr pada percobaan keempat. Hal ini diperoleh dari selisih massa awal tabung gas dan isi $\left(M_{0}\right)$ sebesar $7.862 \mathrm{gr}$ terhadap massa akhir tabung gas dan isi $\left(M_{l}\right)$ sebesar 7.828 gr.

5. masssa LPG yang digunakan $\left(\dot{M}_{b}\right)$ sebesar 35 gr pada percobaan kelima. Hal ini diperoleh dari selisih massa awal tabung gas dan isi $\left(M_{0}\right)$ sebesar 7.828 gr terhadap massa akhir tabung gas dan isi $\left(\mathbf{M}_{1}\right)$ sebesar 7.793 gr.
Massa LPG yang digunakan $\left(\dot{M}_{b}\right)$ pada kondisi putaran mesin $(n) 1.900 \mathrm{rpm}$, waktu pemakaian LPG $(\Delta t)$ 15 menit $(0,25$ jam $)$ dan beban mata parut kelapa yang sama, nilai terendah diperoleh pada percobaan keempat sebesar 34 gr, dan tertinggi pada percobaan ketiga sebesar 38 gr. Besarnya selisih massa LPG yang digunakan $\left(\dot{M}_{b}\right)$ tertinggi dan terendah sebesar 4 gr.

Untuk mengetahui konsumsi bahan bakar LPG $\left(\dot{M}_{f}\right)$ dihitung dengan menggunakan persamaan 1, sebagai berikut:

$$
\dot{M}_{f}=\frac{\dot{M}_{b}}{\Delta t}
$$

$\dot{M}_{f} \quad=$ konsumsi bahan bakar $(\mathrm{gr} / \mathrm{det})$ atau $(\mathrm{kg} / \mathrm{jam})$

$\dot{M}_{b}=$ massa bahan bakar (gr) atau (kg)

$\Delta t \quad$ = waktu yang diperlukan (det) atau (jam)

Berdasarkan hasil perhitungan dengan menggunakan persamaan 1, maka diperoleh konsumsi bahan bakar LPG pada mesin parut kelapa berbahan bakar gas dapat dilihat pada tabel 6. Massa bahan bakar $\left(\dot{M}_{b}\right)$ dikonversi satuannya dari gr menjadi $\mathrm{kg}$. $(1 \mathrm{~kg}=$ $1.000 \mathrm{gr})$.

Tabel 6. Data hasil perhitungan konsumsi bahan bakar

\begin{tabular}{ccccc}
\multicolumn{5}{c}{ LPG } \\
\hline $\begin{array}{c}\text { Percb } \\
\text { ke }\end{array}$ & $\begin{array}{c}n \\
(\mathrm{rpm})\end{array}$ & $\begin{array}{c}\Delta t \\
(\mathrm{mnt})\end{array}$ & $\begin{array}{c}\dot{M}_{b} \\
(\mathrm{~kg})\end{array}$ & $\begin{array}{c}\dot{M}_{f} \\
(\mathrm{~kg} / \\
\mathrm{jam})\end{array}$ \\
\hline 1 & 1.900 & 15 & 0,036 & 0,144 \\
\hline 2 & 1.900 & 15 & 0,037 & 0,148 \\
\hline 3 & 1.900 & 15 & 0,038 & 0,152 \\
\hline 4 & 1.900 & 15 & 0,034 & 0,136 \\
\hline 5 & 1.900 & 15 & 0,035 & 0,140 \\
\hline & & & &
\end{tabular}

Pada tabel 6, diketahui bahwa konsumsi bahan bakar LPG $\left(\dot{M}_{f}\right)$ tertinggi diperoleh pada percobaan ketiga sebesar $0,152 \mathrm{~kg} / \mathrm{jam}$, dan terendah diperoleh pada percobaan keempat sebesar $0,136 \mathrm{~kg} / \mathrm{jam}$. Besarnya selisih konsumsi bahan bakar LPG $\left(\dot{M}_{f}\right)$ tertinggi dan terendah sebesar $0,016 \mathrm{~kg} / \mathrm{jam}$.

Sedangkan untuk mengetahui biaya bahan bakar gas LPG yang dipakai $\left(B_{b b g}\right)$, dihitung dengan menggunakan persamaan 2 .

$$
B_{b b g}=\dot{M}_{f} x H_{b b g}
$$

$B_{b b g} \quad=$ biaya bahan bakar gas LPG $(\mathrm{Rp} / \mathrm{jam})$

$\dot{M}_{f} \quad=$ konsumsi bahan bakar LPG $(\mathrm{kg} / \mathrm{jam})$

$H_{b b g} \quad=$ harga bahan bakar gas LPG $(\mathrm{Rp} / \mathrm{kg})$ 
Dari hasil perhitungan dengan menggunakan persamaan 2 diperoleh, biaya bahan bakar LPG $\left(B_{b b g}\right)$ pada tabel 9. Harga bahan bakar LPG $3 \mathrm{~kg}$ pada saat percobaan dilaksanakan sebesar Rp 18.000,-, sehingga harga bahan bakar LPG $\left(H_{b b g}\right)$ sebesar Rp 6.000,- / kg.

Tabel 9. Data hasil perhitungan biaya bahan bakar LPG

\begin{tabular}{|c|c|c|c|c|}
\hline $\begin{array}{c}\text { Percb } \\
\text {. ke }\end{array}$ & $\begin{array}{c}n \\
(\mathrm{rpm})\end{array}$ & $\begin{array}{c}\dot{M}_{f} \\
(\mathrm{~kg} / \\
\text { jam) }\end{array}$ & $\begin{array}{c}\left(\mathrm{H}_{b b g}\right) \\
(\mathrm{Rp} / \\
\mathrm{kg})\end{array}$ & $\begin{array}{l}B_{b b g} \\
(\mathrm{Rp} / \\
\text { jam) }\end{array}$ \\
\hline 1 & 1.900 & 0,144 & 6.000 & 864 \\
\hline 2 & 1.900 & 0,148 & 6.000 & 888 \\
\hline 3 & 1.900 & 0,152 & 6.000 & 912 \\
\hline 4 & 1.900 & 0,136 & 6.000 & 816 \\
\hline 5 & 1.900 & 0,140 & 6.000 & 840 \\
\hline
\end{tabular}

Pada tabel 9, dapat dilihat bahwa biaya bahan bakar gas LPG $\left(B_{b b g}\right)$ tertinggi diperoleh pada percobaan ketiga sebesar 912 Rp/jam, dan terendah sebesar 816 Rp/jam pada percobaan keempat.

\section{PENUTUP}

\section{Simpulan}

Berdasarkan hasil dan pembahasan yang telah dilakukan dapat diambil simpulan sebagai berikut:

1. penelitian eksperimen dilakukan pada kondisi putaran mesin (n) 1.900 rpm, waktu pemakaian LPG ( $\Delta t) 15$ menit $(0,25$ jam $)$ dan beban mata parut kelapa yang sama.

2. massa LPG yang digunakan $\left(\dot{M}_{b}\right)$ nilai terendah diperoleh pada percobaan keempat sebesar 34 gr, dan tertinggi pada percobaan ketiga sebesar 38 gr. Besarnya selisih massa LPG yang digunakan $\left(\dot{M}_{b}\right)$ tertinggi dan terendah sebesar $4 \mathrm{gr}$.

3. konsumsi bahan bakar LPG $\left(\dot{M}_{f}\right)$ tertinggi diperoleh pada percobaan ketiga sebesar $0,152 \mathrm{~kg} / \mathrm{jam}$, dan terendah diperoleh pada percobaan keempat sebesar $0,136 \mathrm{~kg} / \mathrm{jam}$. Besarnya selisih konsumsi bahan bakar LPG $\left(\dot{M}_{f}\right)$ tertinggi dan terendah sebesar 0,016 $\mathrm{kg} / \mathrm{jam}$.

4. biaya bahan bakar gas LPG $\left(B_{b b g}\right)$ tertinggi diperoleh pada percobaan ketiga sebesar 912 Rp/jam, dan terendah sebesar $816 \mathrm{Rp} / \mathrm{jam}$ pada percobaan keempat. Besarnya selisih biaya bahan bakar gas LPG $\left(B_{b b g}\right)$ tertinggi dan terendah sebesar 96 Rp/jam.

\section{Saran}

Untuk mengurangi adanya perbedaan hasil pengukuran, maka perlu diadakan penelitian lebih lanjut dengan menggunakan instrumen pengukuran yang real time dengan menggunakan data akusisi.

\section{Ucapan Terima Kasih}

Terima kasih. Artikel ini merupakan bagian dari penelitian yang berjudul "Rancang bangun mesin parut kelapa dengan menggunakan bahan bakar gas" yang dibiayai oleh Direktorat Riset dan Pengabdian Masyarakat (DRPM), Direktorat Jenderal Penguatan Riset dan Pengembangan tahun 2018.

\section{DAFTAR PUSTAKA}

Alfatani, A., 2015. Pengaruh Putaran Mesin Terhadap Konsumsi Bahan Bakar Pada Mesin Matari Mgx 200/Sl (Doctoral Dissertation, Um Pontianak).

Ariawan, BWI, Kusuma, WBGI \& Adnyana, BWI. 2016. Pengaruh Penggunaan Bahan Bakar Pertalite Terhadap Unjuk Kerja Daya, Torsi Dan Onsumsi Bahan Bakar Pada Sepeda Motor Bertransmisi Otomatis. Jurnal METTEK Volume 2 No 1 hal. 5158 ISSN 2502-3829.

Bambang, EB, Listiasri, E \& Kusuma, CG. 2015. Alat Pendeteksi Dini Terhadap Kebocoran Gas LPG. Junal TELE Volume 13 Nomor 1 Hal. 1-6.

Hardono, Joko. 2017. Rancang Bangun Mesin Pemarut Kelapa Skala Rumah Tangga Berukuran $1 \mathrm{Kg}$ Per Waktu Parut 9 Menit Dengan Menggunakan Motor Listrik 100 Watt. Motor Bakar Jurnal Teknik Mesin UMT Volume 1 Nomor 1.

http://list-harga.com/harga-gas-elpiji-terbaru-bulanmaret-2017/ diakses 12 Juni 2017

http://www.bphmigas.go.id/harga-bbm-di-spbu diakses diakses 12 Juni 2017

http://www.autogasindonesia.com/product/diakses tanggal 28 Agustus 2018

Operation manual book, Digital Photo Tachometer Model: DT-2234C

Operation manual sheet, Timbangan Digital $40 \mathrm{~kg}$

Operation manual book, Mesin penggerak Laqoni Forza $5,5 \mathrm{hp}$

Ramelan, Utomo. 2015. Peningkatan Efisiensi Bahan Bakar Dengan Metode Cyclon Melalui Pemasangan Swirling Vane Pada Sepeda Motor. Jurnal AUTINDO Politeknik Indonusa Surakarta ISSN: 2442-7918 Vol.1 Nomor 2 Hal. 42-47.

Renstra Kementrian Energi dan Sumber Daya Mineral (ESDM), Direktorat Jendral Minyak dan Gas Bumi, tahun 2015-2019.

Singh, H, Kumar, C, Yadaf, KD, Yadav, KA, Nishad A, Verma, KA \& Pandey, KA. 2015. Conversion Of Petrol Bike Into Lpg And Emission Check. 
International Journal Of Mechanical Engineering And Technology (IJMET) ISSN 0976 - 6340 (Print) ISSN 0976 - 6359 (Online) Volume 6, Issue 4, pp. $65-71$

Subagio, Achmad. 2011. Potensi Daging Buah Kelapa sebagai Bahan Baku Pangan Bernilai. Jurnal PANGAN, Vol. 20 No. 1 hal: 15-26

Yohana, Eflita \& Askhabulyamin. 2012. Perhitungan Efisiensi Dan Konversi Dari Bahan Bakar Solar Ke Gas Pada Boiler Ebara Hkl 1800 KA. Jurnal Rotasi vol.14 no. 2 hal 7-10.

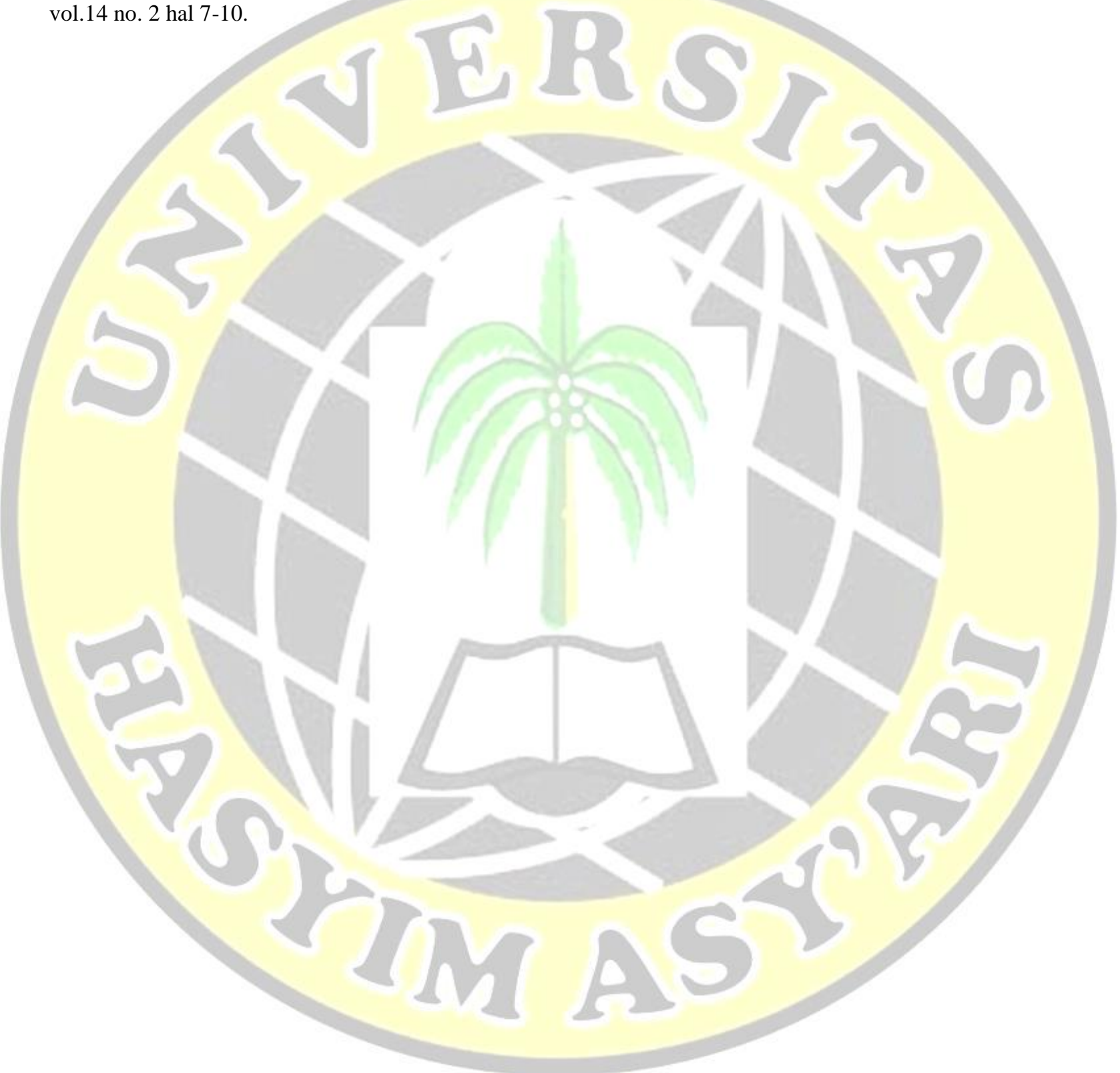

